University of Nebraska - Lincoln

DigitalCommons@University of Nebraska - Lincoln

Faculty Publications from the Harold W. Manter Laboratory of Parasitology

6-1981

\title{
A New Species of Echinocephalus (Nematoda: Gnathostomidae) from Neotropical Stingrays with Comments on E. diazi
}

Thomas L. Deardorff

Smithsonian Institution

Daniel R. Brooks

University of Toronto,dnlbrooks@gmail.com

Thomas B. Thorson

University of Nebraska-Lincoln

Follow this and additional works at: https://digitalcommons.unl.edu/parasitologyfacpubs

Part of the Parasitology Commons

Deardorff, Thomas L.; Brooks, Daniel R.; and Thorson, Thomas B., "A New Species of Echinocephalus (Nematoda: Gnathostomidae) from Neotropical Stingrays with Comments on E. diazi" (1981). Faculty Publications from the Harold W. Manter Laboratory of Parasitology. 264.

https://digitalcommons.unl.edu/parasitologyfacpubs/264

This Article is brought to you for free and open access by the Parasitology, Harold W. Manter Laboratory of at DigitalCommons@University of Nebraska - Lincoln. It has been accepted for inclusion in Faculty Publications from the Harold W. Manter Laboratory of Parasitology by an authorized administrator of DigitalCommons@University of Nebraska - Lincoln. 


\title{
A NEW SPECIES OF ECHINOCEPHALUS (NEMATODA: GNATHOSTOMIDAE) FROM NEOTROPICAL STINGRAYS WITH COMMENTS ON E. DIAZI
}

\author{
Thomas L. Deardorff, ${ }^{\star}$ Daniel R. Brooks, $\dagger$ and Thomas B. Thorson $\ddagger$
}

ABSTRACT: Echinocephalus daileyi sp. n. is described from the freshwater stingrays Potamotrygon circularis and P. hystrix in South America. It is most similar to E. diazi by virtue of possessing a gubernaculum and six postanal papillae, but may be distinguished from $E$. diazi and other members of the genus by possessing 30 to 34 rows of spines on the cephalic bulb, three preanal papillae, and a body 55 to 85 $\mathrm{mm}$ long. Specimens of $E$. diazi were collected from Himantura schmardae, the type host, from Cienaga Grande, Colombia, a new locality record. Based on numerical phylogenetic analysis, E. daileyi is a member of a monophyletic group including E. sinensis, E. diazi, and E. pseudouncinatus.

Examination of marine and freshwater stingrays in northern South America during 1975 to 1978 revealed the presence of two species of Echinocephalus Molin, 1858. One of those species is described herein as new, and a new locality record is reported for the other.

Specimens were removed from hosts, fixed in $10 \%$ formalin or in glacial acetic acid, stored in a solution of five parts glycerin and 95 parts $70 \%$ ethanol, then examined in glycerin after evaporation of the alcohol. All measurements are in micrometers unless otherwise stated, and figures were drawn with the aid of a drawing tube.

\section{Echinocephalus daileyi sp. $\mathrm{n}$.}

(Figs. 1-12)

\section{Description}

Based on specimens from Potamotrygon circularis. Body unarmed, reaching greatest width posterior to midbody. Pseudolabia oriented dorsoventrally, equal in size, wider than long, two in number, each with two lateral double papillae and one medial amphid on surface and with two cuticularized toothlike structures; internal pulp pedunculate, trilobed. Dentigerous ridges and interlabia lacking. Cuticle with inconspicuous annulations. Dereids 0.9 to $1.1 \mathrm{~mm}$ from anterior extremity. Cephalic bulb armed with spines in

Received 20 March 1980; accepted 23 October 1980.

* Gulf Coast Research Laboratory, Ocean Springs, Mississippi 39564.

$\dagger$ Department of Animal Pathology, National Zoological Park, Smithsonian Institution, Washington, D.C. 20008.

$\ddagger$ School of Life Sciences, University of NebraskaLincoln, Lincoln, Nebraska 68588. transverse rows; rows slightly more compact near anterior and posterior ends of bulb, with maximal separation near midbulb; some rows not continuous; spines uncinate, larger near midbulb, not overlapping adjacent rows; bulb containing four ballonets. Cuticular collar present. Cervical sacs extending from ballonets just anterior of muscularglandular junction of esophagus, reaching greatest width near posterior extremity, four in number. Esophagus 6 to $11 \%$ total body length, divided near midpoint into anterior muscular and posterior glandular regions. Nerve ring located at anterior 12 to $23 \%$ of esophagus. Tail conical, with blunt tip; tip without ornamentation.

Male (based on five whole specimens and five tail fragments): Body 55 to $66 \mathrm{~mm}$ long by 0.6 to 0.9 $\mathrm{mm}$ wide at greatest width; ratio of greatest width to length $1: 67$ to 83 . Pseudolabia 154 to 184 long by 278 to 309 wide. Cephalic bulb 438 to 525 long by 605 to 646 wide, with 30 to 32 rows of cephalic spines; spines 4 to 9 long. Nerve ring 0.8 to $1.0 \mathrm{~mm}$ from anterior extremity, 24 to 43 in breadth. Cervical sacs 1.5 to $2.2 \mathrm{~mm}$ long by 78 to 173 wide at greatest width. Esophagus 6 to $11 \%$ total body length, 3.6 to $6.2 \mathrm{~mm}$ long; muscular esophagus 1.6 to $3.4 \mathrm{~mm}$ long by 283 to 362 wide; glandular esophagus 2.0 to $3.2 \mathrm{~mm}$ long by 378 to 535 wide; ratio of glandular esophageal to muscular esophageal lengths $1: 0.7$ to 1.4 . Spicules similar, equal in length, 2.7 to $3.6 \%$ total body length, 1.4 to $2.4 \mathrm{~mm}$ long by 31 to 37 wide. Gubernaculum V-shaped, 96 to 185 long. Caudal alae united ventrally, surrounding cloaca, 0.5 to $1.2 \mathrm{~mm}$ long, supporting nine pairs of caudal papillae; preanal pairs three, of unequal length, with midpair largest and most lateral; postanal pairs six, of unequal length, with first pair from extremity extremely small, with third pair most lateral and largest, with sixth pair immediately posterior to anus. Medioventral preanal organ distinct, papillated. Modified annules on ventral surface near caudal alae, extending anteriorly 2.2 to $3.7 \mathrm{~mm}$ or 4 to $6 \%$ total body length. Phasmids paired near end of tail. Tail 339 to 568 long.

Female (based on eight mature specimens): Body 55 to $85 \mathrm{~mm}$ long by 0.9 to $1.4 \mathrm{~mm}$ wide at greatest width; ratio of greatest width to length $1: 46$ to 71 . 

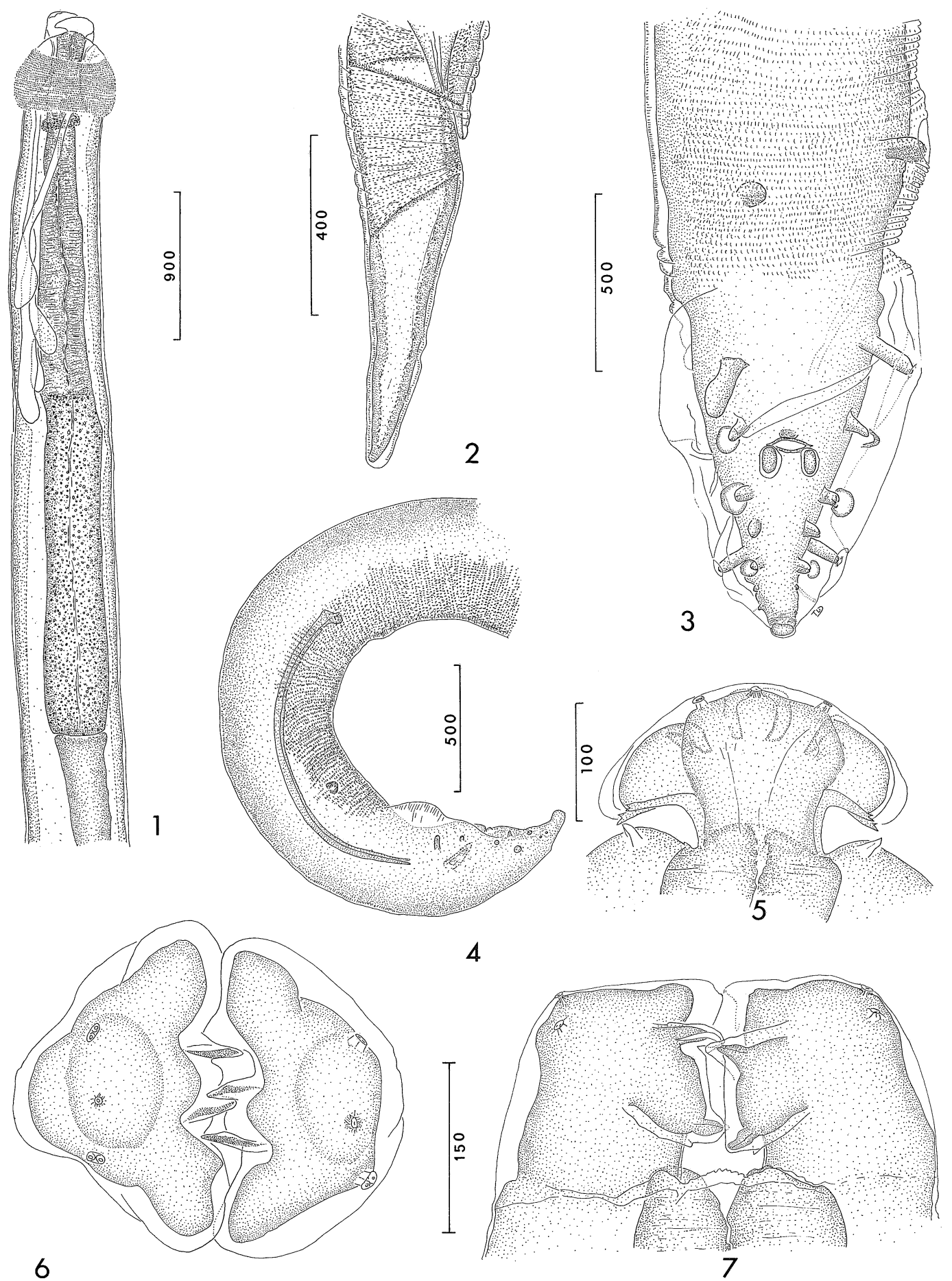

FIGURES 1-7. Echinocephalus daileyi. 1. Anterior end showing relationship between pre-esophagus and post-esophagus. 2. Posterior end of female tail, lateral view. 3. Posterior end of male showing caudal papillae and ventral annules, ventral view. 4. Posterior end of male showing spicules and gubernaculum. 5. Dorsal view of lip. 6. En face. 7. Lateral view of lips. 

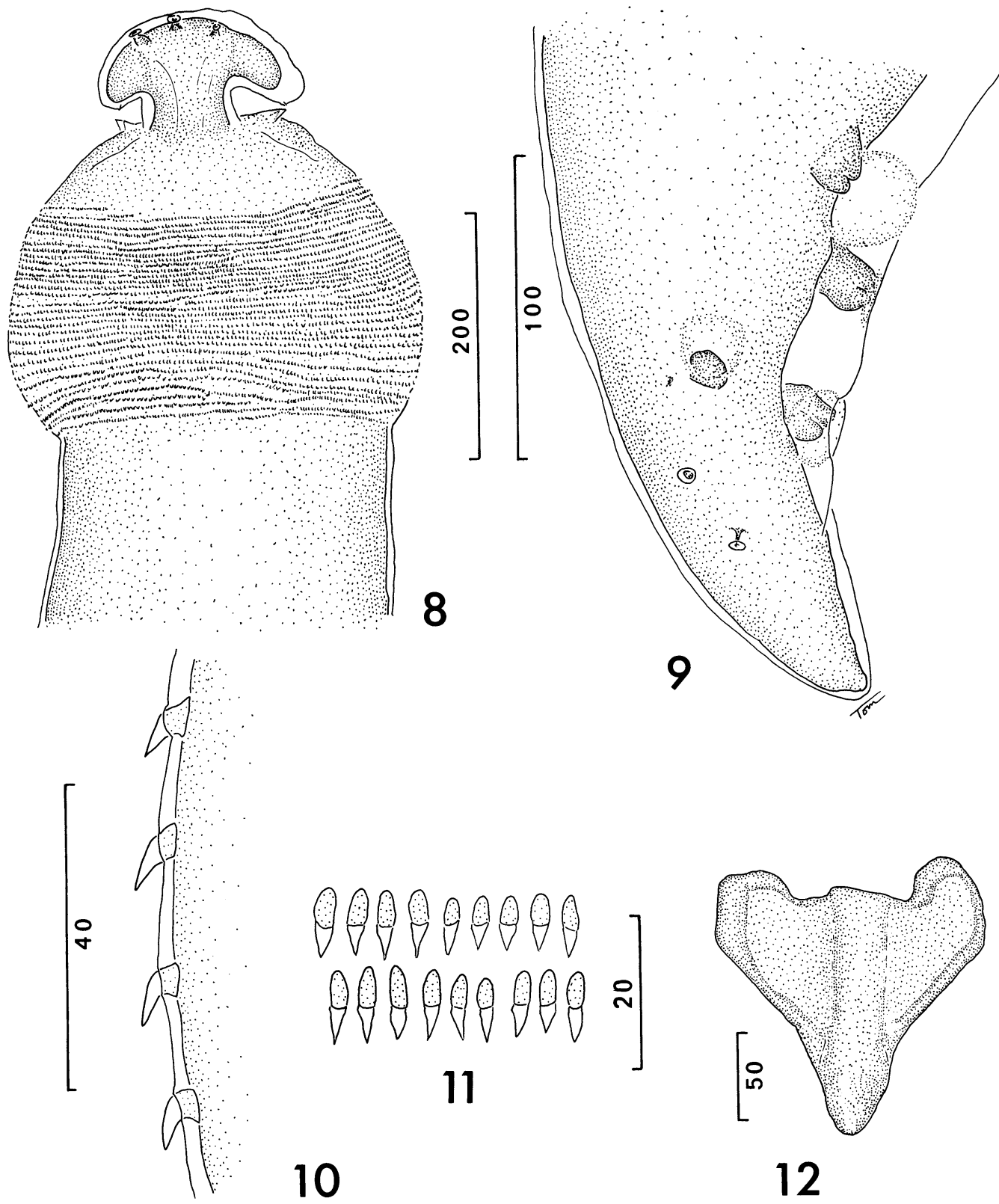

FigurEs 8-12. Echinocephalus daileyi. 8. Anterior extremity of male showing cephalic bulb and rows of spines. 9. Posterior extremity of male showing phasmid and postanal papillae, lateral view. 10. Cephalic spines attached to cephalic bulb, lateral view. 11. Cephalic spines, dorsal view. 12. Gubernaculum, ventral view.

Pseudolabia 154 to 236 long by 296 to 378 wide. Cephalic bulb 475 to 677 long by 587 to 803 wide, with 30 to 34 rows of spines; spines 4 to 12 long. Nerve ring 0.7 to $1.2 \mathrm{~mm}$ from anterior extremity, 37 to 78 in breadth. Cervical sacs 1.9 to $2.8 \mathrm{~mm}$ long by 60 to 267 at greatest width. Esophagus 7 to $11 \%$ total body length, 5.4 to $6.6 \mathrm{~mm}$ long; muscular esophagus 2.8 to $3.6 \mathrm{~mm}$ long by 166 to 394 wide; glandular esophagus 2.3 to $3.4 \mathrm{~mm}$ long by 315 to 551 wide; ratio of glandular esophageal to muscular esophageal lengths 1:0.8 to 1.5. Vulva opening 1.5 to $2.4 \mathrm{~mm}$ or 2 to $4 \%$ total body length from poste- 
rior extremity. Uterus didelphic, prodelphic. Eggs with smooth thin shell, oval, 14 to 43 long by 18 to 50 wide. Tail 724 to 961 long.

\section{Type specimens}

Holotype: Male, USNM Helm. Coll. No. 76094. Allotype: Female, USNM Helm. Coll. No. 76095.

Paratypes: USNM No. 76096, University of Nebraska State Museum, H. W. Manter Laboratory No. 21172 (pair).

Hosts: Type host-Potamotrygon circularis (Garman); Other host-Potamotrygon hystrix (Muller and Troschel).

Localities: Colombia: nr. Leticia (type locality). BraziL: Río Itacuai. Venezuela: Delta of Río Orinoco, nr. Curiapo.

Site of infection: Intestine, immediately anterior to spiral valve.

Etymology: This species is named for Dr. Murray D. Dailey, California State University, Long Beach, in recognition of his contributions to our knowledge of elasmobranch helminths.

\section{Remarks}

By possessing a gubernaculum, Echinocephalus daileyi most closely resembles $E$. sinensis Ko, 1975, E. diazi Troncy, 1969, and E. pseudouncinatus Millemann, 1951. Both Millemann (1963) and Ko (1975) reported that E. pseudouncinatus lacked a gubernaculum, but our examination of a male deposited in the National Museum by Millemann from Myliobatis californicus in the Gulf of California, Mexico (USNM Helm. Coll. No. 57450 ), clearly showed a gubernaculum to be present. The new species differs from E. sinensis by exhibiting six rather than five postanal papillae and three rather than two preanal papillae, and by possessing 30 to 34 rather than 26 to 29 rows of cephalic bulb spines. Echinocephalus daileyi differs from E. diazi and E. pseudouncinatus by having more rows of cephalic bulb spines; $E$. diazi has 25 to 27 rows and E. pseudouncinatus has 16 to 21 . By exhibiting three rather than six postanal papillae, E. pseudouncinatus is unique among members of the genus. Lastly, $E$. daileyi differs from $E$. diazi by having three rather than two preanal papillae. Echinocephalus daileyi represents the first member of the genus known from freshwater stingrays (Potamotrygonidae).

\section{Echinocephalus diazi Troncy, 1969}

Troncy (1969) described E. diazi from Lake Maracaibo, Venezuela, and listed Potamotry-

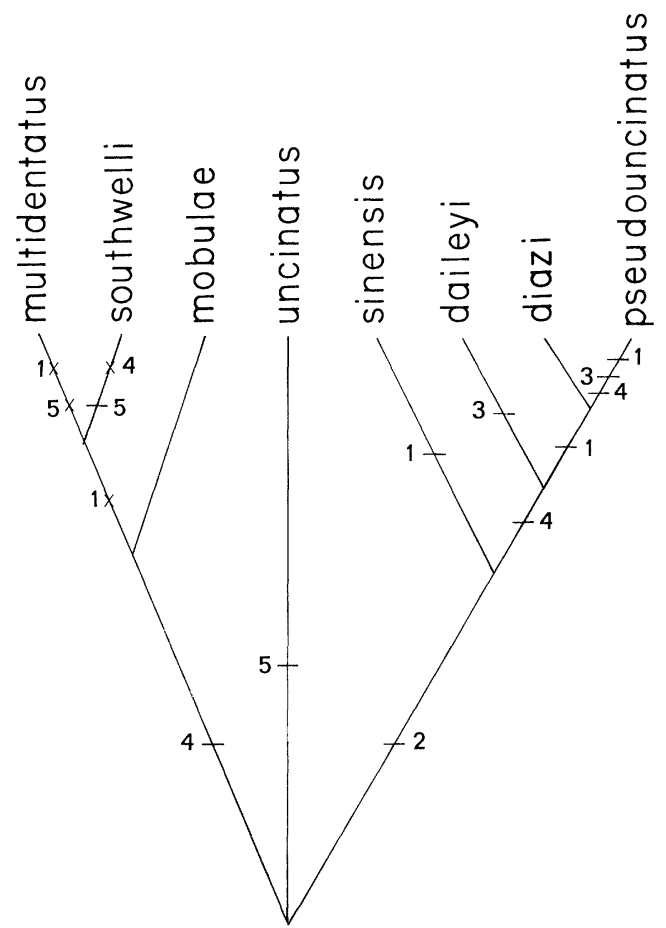

FIGURE 13. Cladogram depicting genealogical relationships of eight species of Echinocephalus. Slash marks indicate derived states for characters indicated by accompanying number. Single slash refers to character state with a positive notation, $\mathrm{x}$-slash marks refer to character states with a negative notation. For identities of characters, see text.

gon hystrix as host. However, Diaz-Ungria (1973) listed as host the euryhaline dasyatid ray Himantura schmardae Werner. The latter host record is confirmed by our collection of E. diazi from $H$. schmardae captured near the northern edge of the Cienaga Grande, vicinity of Santa Marta, Colombia, a new locality record. Our specimens, one male and seven females, agree with the description of $E$. diazi by Troncy with the exception of the total body length, 15 to 26 rather than 30 to $45 \mathrm{~mm}$, spicule length, 0.8 rather than $2.0 \mathrm{~mm}$, and spicule length expressed as a proportion of body length, $3.6 \%$ on a 22 -mm-long male rather than $4.7 \%$ on a 42 -mm-long male. The discrepancies may be a result from our small sample size.

\section{DISCUSSION}

Specificity in site of infection was pronounced in each of the two species collected. 


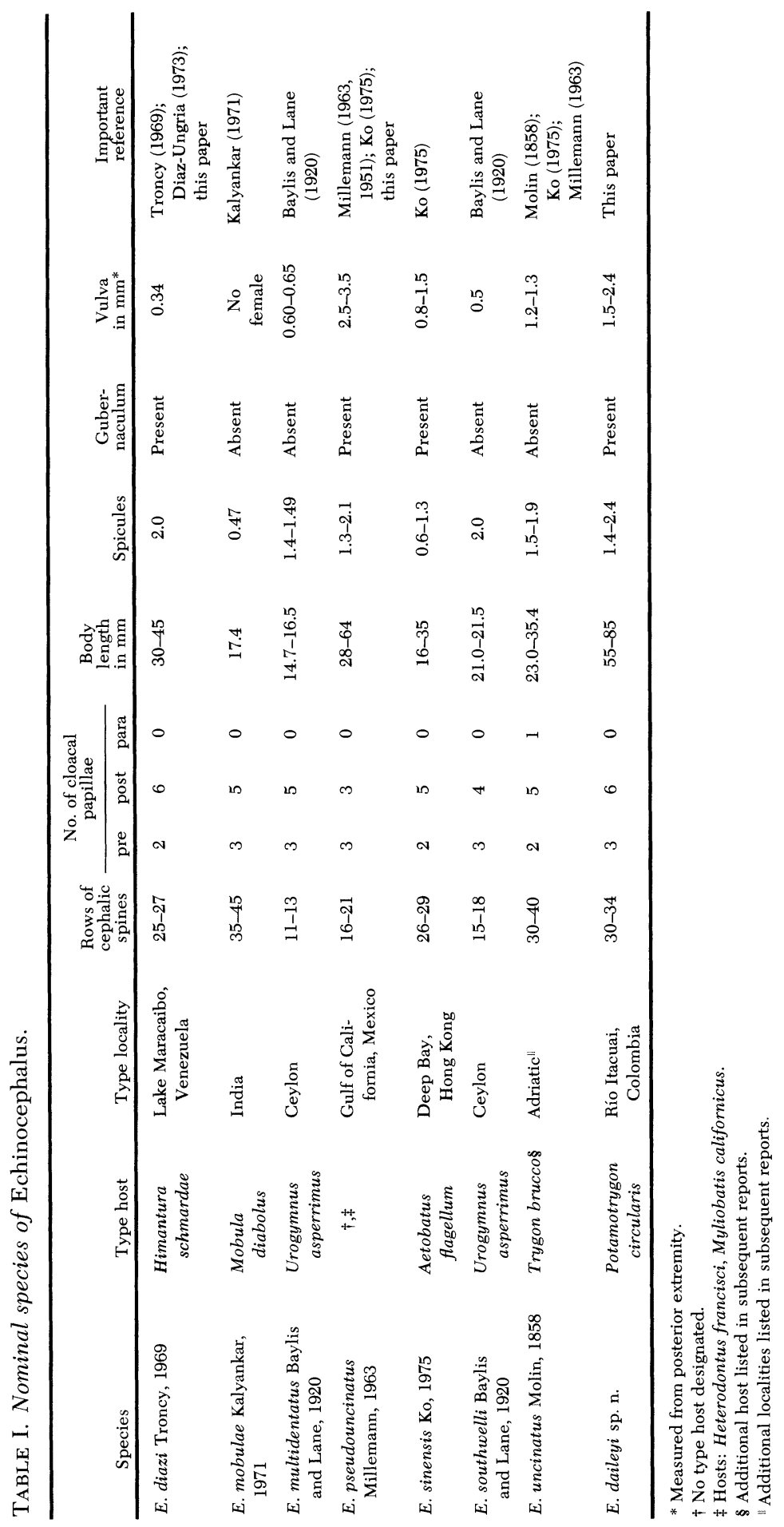


Specimens of E. diazi occurred highly localized in the intestine just posterior to the spiral valve, whereas $E$. daileyi occurred highly localized immediately anterior to the spiral valve. In all cases, a visible, associated nodule occurred on the exterior of the intestine at the site of the worm's localization.

To better understand the phylogenetic relationships of $E$. daileyi, infecting freshwater stingrays, to those species of Echinocephalus infecting marine rays, we classified the new species and its seven closest relatives according to the method proposed by Hennig (1966). Hennigian, or phylogenetic, systematics produces branching diagrams (cladograms) in which taxa are clustered according to the presence of one or more shared special traits (synapomorphies). Generalized or primitive traits are uninformative in a phylogenetic sense because they conform to any hypothesis of relationships whatever, and therefore, are included on the cladogram a posteriori to the clustering. Clustering taxa according to shared special traits produces internested sets of monophyletic groups. Clustering by shared primitive traits (synplesiomorphies), either wholly or in part, produces classifications comprising paraphyletic or polyphyletic groups.

Pending a complete revision of the genus, we accept the provisional synonymies presented by Yamaguti (1962) and Millemann (1963). They recognized E. uncinatus Molin, 1858 (=E. gracilis Stossich, 1906, E. spinosissimus [Von Linstow, 1905], and E. aetabati MacCallum, 1921), E. multidentatus Baylis and Lane, 1920, E. southwelli Baylis and Lane, 1920, and E. pseudouncinatus Millemann, 1951. Subsequently, E. diazi, E. sinensis, E. daileyi, and E. mobulae Kalyankar, 1971 have been described. Our classification of the above eight species is based on the following characters as presented in their original descriptions and their coded states (see Table I for a more complete data display):

1. Number of rows of cephalic bulb spines. $0=30-45 ; 1=25-29 ; 2=16-21 ;-1=$ $15-18,-2=11-13$.

2. Presence or absence of a gubernaculum. $0=$ lacking; $1=$ present.

3. Number of preanal papillae. $0=2 ; 1=3$.

4. Number of postanal papillae. $0=5 ; 1=6$; $2=3 ;-1=4$.
5. Number of pseudolabial teeth. $0=6 ; 1=$ $4 ;-1=8-11$.

Echinocephalus crassostreai Cheng, 1975 and E. muraenesocis Bilqees, Khanum, and Jehan, 1971 were not included in our cladogram or table, because the former is obviously the third-stage larval form of E. sinensis and the latter was described inadequately.

The characters listed above depict the group sinensis-daileyi-diazi-pseudouncinatus as a monophyletic group, but incompletely resolve the relationships of the remaining four taxa (Fig. 13). Future studies should provide additional useful characters.

\section{ACKNOWLEDGMENTS}

We are grateful for major support from $\mathrm{Na}$ tional Geographic Society grants to T.B.T.; supplementary funds from the University of Nebraska-Lincoln Research Council; and permission for D.R.B. and T.B.T. to accompany the R/V Eastward collecting cruise in the Orinoco Delta, financed by a National Science Foundation grant to John G. Lundberg and Jonathan N. Baskin.

We appreciate the substantial aid of Orlando Mora Lara, Alvaro Boada Guarin, Francisco Mago Leccia, Mike Tsalickis, and Monte A. Mayes.

\section{LITERATURE CITED}

BAYlis, H. A., AND C. LANE. 1920. A revision of the nematode family Gnathostomatidae. Proc. Zool. Soc. Lond., Sept., pp. 245-310.

Bilqees, F. M., Z. Khanum, AND Q. Jehan. 1971. Marine fish nematodes of West Pakistan. I. Description of seven new species from Karachi Coast. J. Science. 1: 175-184.

DiAz-UNGRIA, C. 1973. Helmintos endoparasitos de Venezuela. Cienc. Vet. 3: 37-242.

Hennig, W. 1966. Phylogenetic systematics. Univ. Ill. Press, Urbana, Illinois, 263 p.

KALYANKAR, S. D. 1971. On a new species of Echinocephalus Molin, 1858 (Nematoda: Gnathostomatidae: Echinocephalinae) from India, with a key to the species. Zool. Anz. 187: 317320.

Ko, R. C. 1975. Echinocephalus sinensis n. sp. (Nematoda: Gnathostomatidae) from the ray (Aetabatus flagellum) in Hong Kong, Southern China. Can. J. Zool. 53: 490-500.

MillemanN, R. E. 1951. Echinocephalus pseudouncinatus n. sp., a nematode parasite of the abalone. J. Parasitol. 3 7: 435-439.

- 1963. Studies on the taxonomy and life history of echinocephalid worms (Nematoda: Spiruroidea) with a complete description of Echi- 
nocephalus pseudouncinatus Millemann, 1951. Troncy, P. M. 1969. Description de deux nouJ. Parasitol. 49: 754-764.

MoLIN, R. 1858. Prospectus helminthum, quae in prodromo faunae helminthologicae Venetiae continentur. Sitzungsber Akad. Wiss. Wien Math. Naturwiss. Kl. Abt. 3, 14: 127-158.

velles espècies de nématodes parasites de poissons. Bull. Museum Nat. Hist. Nat 41: 598605.

YamaGUTI, S. 1962 (1961). Systema Helminthum. Vol. III. The nematodes of vertebrates. 2 parts. Interscience, New York. 1261 p. 